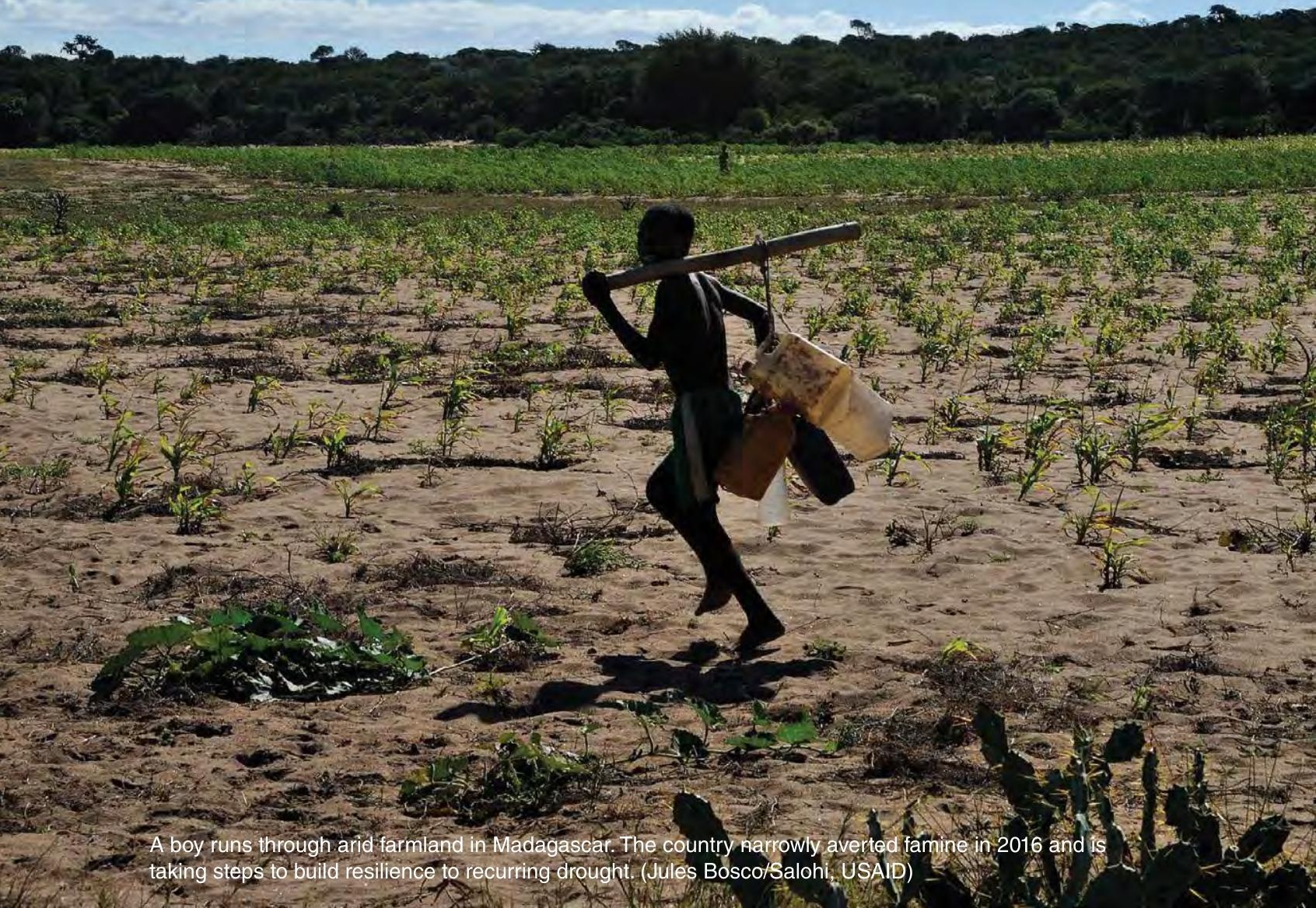

\title{
7
}

\section{Nutritional Ecology: Understanding the Intersection of Climate/Environmental Change, Food Systems and Health}

\author{
Daniel J. Raiten ${ }^{1 *}$ and Gerald F. Combs ${ }^{2}$
}

${ }^{1}$ Eunice Kennedy Shriver National Institute of Child Health and Human Development, National Institutes of Health, Bethesda, Maryland, USA; ' Jean Mayer USDA Human Nutrition Research Center on Aging, Tufts University, Boston, Massachusetts, USA and Cornell University, Ithaca, New York, USA

\footnotetext{
* Corresponding author: raitend@mail.nih.gov
} 


\section{The Challenge}

The year 2017 was, for the earth in general, the most recent of a string of the 40 warmest years on record (NOAA NCEI, 2017; Whitmee et al., 2015). Global warming is associated with a variety of environmental sequelae involving air, water, temperature and adverse weather patterns affecting land and water resources and ultimately quality of life via changes in habitat and food production. As the earth's human population is expected to reach 9.7 billion by the middle of this century, providing a booming population with healthy diets will call for an estimated doubling of global annual food production (UN DESA, 2017).

The world has not been able to provide sufficient food (either via sustainable local production or distribution of current food supplies) for the poor and most vulnerable people to be able to access healthy, diverse diets. The 2017 UN report on The State of Food Security and Nutrition in the World noted that 'After steadily declining for over a decade, global hunger is on the rise again, affecting 815 million people in 2016 , or 11 percent of the global population' (FAO et al., 2017). In addition to hunger, the UN report pointed out that malnutrition, caused by unbalanced diets, is likely to affect many more people. For example, iron, iodine, and vitamin A deficiencies affect more than 2 billion people, most prominently women, infants, and children (Bailey et al., 2015).

The UN report highlighted climate/environmental change (CEC) as a primary driver of this recent upturn in the prevalence of hunger and malnutrition, emphasizing that these outcomes involve both the sizes and nutritional qualities of national food supplies. Most importantly, the report emphasized that food insecurity and malnutrition are not simply outcomes of agriculture and trade that affect health, but they are also inputs, or factors affecting the health of individuals and populations that, in turn, impact national agricultural and economic development. This means that CEC has the clear potential to threaten global efforts to assure food and nutrition security, to promote human welfare, and to facilitate national development.

The challenge, therefore, is to address the realities of CEC in ways that sustain the growth of agricultural productivity, guard the nutritional value of food supplies, and promote health and opportunities for developing societies.
In meeting this challenge, it will be necessary to consider human nutrition and health as key features of food systems. In that light, this chapter addresses the intersection of CEC, food systems, nutrition and health. It presents the case for how an ecological approach can clarify the relationships of food systems and human nutritional status, and the role of the latter as both an input and outcome of human health. It also argues that considering nutritional ecology in addressing CEC is likely to reduce risks of unintended consequences.

\section{Climate/Environmental Change (CEC)}

CEC is profoundly changing the global ecology and quality of life. It is affecting food systems, already challenged by the growing needs of an expanding global population with its record uses of energy, water, and land resources (Whitmee et al., 2015). Rising levels of carbon dioxide $\left(\mathrm{CO}_{2}\right)$ may reduce the nutritional quality of crops and crop yields, and cause increases in populations of crop pests as well as increases in animal and human parasites and pathogenic microbes. The latter effects would very likely lead to increased use of pesticides and veterinary drugs, which could result in increased toxic residues in foods. Extreme weather events are likely to affect food supplies by impairing trade and other means of food distribution, and by increasing food losses through damage, spoilage and contamination (Ziska et al., 2016).

CEC is also likely to affect the ways and places people live. By increasing sea levels and reducing regular rainfall, CEC is very likely to affect patterns of land use and, hence, population distributions in both coastal and upland regions. Shifts are likely in the location and amount of arable land, shrinking the amount in specific geographical regions, including Africa, South America and Asia, areas already at risk for food insecurity (Zhang and Cai, 2011; Zabel et al., 2014). In addition, CEC is likely to lead to increased accumulation of nitrogen and phosphorus in soils, leading to increased levels in terrestrial ecosystems and wetlands (Hasegawa et al., 2016), losses of plant and animal species diversity (Pauls et al., 2013; Pinkney et al., 2015), and reductions 
in numbers of insect pollinators (Ellis et al., 2015). Food systems are likely to be affected by pressures related to population changes. These pressures include increased mobilization of organic pollutants and rising numbers of refugees impacted by severe weather events and compromised food, social, economic, and health systems (UNHCR, 2018). The following sections focus more directly on the impacts of CEC on specific aspects of the global food supply.

\section{Impacts on fisheries}

The world depends on healthy oceans and their related food systems. However, the world's fisheries and aquacultures face challenges from CEC (FAO, 2016). The World Wildlife Federation (WWF) reported a $49 \%$ reduction in marine fish populations between 1970 and 2012 (WWF, 2015). Several factors have been identified as contributing to these changes, most prominently over-fishing: $31 \%$ of the earth's oceans are over-fished (FAO, 2016). Other factors include rising water temperatures, ocean acidification, and habitat destruction. In addition, evidence suggests that rising levels of atmospheric $\mathrm{CO}_{2}$ are causing major changes in marine food chains, leading to reductions in both the quantity and quality of fish for human consumption (Rossoll et al., 2012; Garzke et al., 2016; Golden et al., 2016). These effects may also involve alterations in the amounts and compositions of marine algae consumed by fish (Gomez-Gutierrez et al., 2011).

As the supplies of marine food sources decline, pressures will increase to identify alternative ways of sustaining marine food production, such as through aquaculture or, alternatively, find other sources of protein nutrition. These effects are likely to have greatest impacts on the traditional diets of people living in low-resource settings. The demise of traditional dietary practices will have health implications such as have been documented by O'Brien et al. (2017). That report showed a rise in the prevalence of vitamin D-deficiency rickets among indigenous native populations in Alaska whose diets had shifted from the traditional sources of marine-based food to more processed foods. The authors did not address whether these shifts reflected changes in fish availability. Nevertheless, the implications are relevant to the concern about the impact of CEC on fisheries as a major source of nutrition to support health particularly in indigenous populations that rely on fish as part of their traditional diet (Golden et al., 2016).

\section{Impacts on plant food sources}

Plant foods are important components of healthy diets. They provide sources of several nutrients not found in most animal tissues, notably xanthophylls, carotenoids, and several vitamins (E, $\mathrm{K}$ and C; thiamin, pantothenic acid and folate). CEC is impacting food plants in several ways. Severe weather events such as droughts and floods can destroy food crops. Changing temperature, precipitation and increases in greenhouse gas emissions (GHGE), most notably $\mathrm{CO}_{2}$ and methane $\left(\mathrm{CH}_{4}\right)$, can reduce yields (Donatelli et al., 2015; Kumar, 2016; Lee et al., 2017). For example, research projects that, by 2050, warming could reduce the world's crop production by more than $10 \%$, even under two different scenarios one with pollution control measures that reduce the surface ozone and another more pessimistic scenario that sees an increase in ozone in most regions (Tai et al., 2014).

GHGE can also impair photosynthesis and reduce disease resistance (Niinemets et al., 2017; Walker et al., 2017). Effects on non-agricultural host plants can lead to reductions in pollinator numbers (Ellis et al., 2015; Brown et al., 2016), and increases in crop pests (Kumar, 2016; Donatelli et al., 2017) which affect yields. Some evidence suggests that CEC can also affect the nutritional value of crops. Ziska et al. (2016) conducted a systematic review of the literature attesting to the impact of CEC on the US food system. They concluded that rising atmospheric $\mathrm{CO}_{2}$ levels were likely to reduce the nutritional value of grains and pulses, by reducing concentrations of protein and at least some essential minerals (e.g. iron, zinc). Another set of researchers (Medek et al., 2017) recently found that under elevated $\mathrm{CO}_{2}$ concentrations, the protein levels of rice, wheat, and barley decreased by $7.6 \%, 7.8 \%$, and $14.1 \%$, respectively, leading them to project that by 2050 an additional 148 million people will be at risk of protein deficiency. 
Research has also suggested that CEC can lead to reduced levels of iron and zinc in grains and legumes (Ziska et al. 2009; Myers et al., 2014, 2015).

CEC may have different effects on crop systems depending on crop and geographic region. For example, Ali et al. (2017) reported both increased and decreased yields of four major food crops (wheat, rice, maize and sugarcane) associated with various aspects of CEC (maximum/ minimum temperature, rainfall) in Pakistan. Similarly, Zhao et al. (2017) found different components of climate change (increased sunlight exposure, reduced humidity, reduced rainfall) to be associated with different effects on spring wheat yields across Inner Mongolia. Thus, decisions about best practices in the face of CEC must take ecological approaches that recognize local contexts, in terms of impact on crop yield, plant nutrient content, and land use patterns/ availability.

\section{Impacts on animal-source foods}

Compared with plants, foods derived from animals tend to be better sources of biologically complete protein, other essential minerals such as bioavailable iron and zinc, and several vitamins, particularly vitamin $B_{12}$ (which is not found in plants). In addition, the gut microbiome of ruminants such as cattle, sheep, and goats can use plant materials like grasses, maize, and wheat stalks that are not digestible by monogastric species, including poultry, pigs, and humans. This feature enables ruminant animals to harvest nutrients over wide areas. Ruminants and monogastrics also provide manure, which has value as both fertilizer and fuel.

These benefits contrast with other features of animal agriculture. First, many animals, particularly monogastrics and grain-fed ruminants, compete with humans for food/feed grains and grain legumes and, thus, for the acreage required to produce those crops. Second, the gut microbiomes of ruminants produce $\mathrm{CH}_{4}$, a potent greenhouse gas. A dairy cow, for example, produces $70-120 \mathrm{~kg}$ of $\mathrm{CH}_{4}$ per year. Methane produced from animal agriculture has been estimated to account for $14.5 \%$ of the world's total anthropogenic GHGE (Gerber et al., 2013). Livestock can also be, in turn, impacted by CEC; research has shown that animals reduce their feed intake by as much as $25-30 \%$ in response to high temperatures (Thornton and Cramer, 2012).

Therefore, decisions about the roles of animal-source foods in human nutrition must consider trade-offs between nutrient production and environmental impact. Such decisions will be facilitated by developing sustainable animal production practices that minimize methane gas emissions (Farchi et al., 2017; Goldstein et al., 2017; White and Hall, 2017), as well as developing alternative sources of protein and vitamin $\mathrm{B}_{12}$ (Latunde-Dada et al., 2016; van Huis, 2016; Henchion et al., 2017).

\section{Impact of CEC on biodiversity}

Some effects of CEC on food systems are manifest through changes in biodiversity at both macro and micro levels (see Chapter 4). At the macroecological level, negative effects on food yields involve loss of pollinators, particularly insects, due to loss of their food species and/or timing of their availability relative to the pollination needs of cultivated crops. These factors have a direct effect on the diversity of agricultural production systems, in turn negatively affecting individuals' abilities to access the diverse diets crucial to good health. In addition, numbers of pest species (Newbery et al., 2016; Ziska and McConnell, 2016; Donatelli et al., 2017) may rise due to degradation of natural habitats. For example, the range of the mountain pine beetle has in recent years expanded to more northern regions, owing to warmer temperatures, leading to a large-scale forest insect blight in North America (Ziska and McConnell, 2016). These effects can be exacerbated by overexploitation of biological resources, pollution, introduction of invasive species and, in the case of oceans, acidification (CBD-WHO, 2015).

At a micro-ecological level, CEC has both direct and indirect impacts on food systems and human health. Negative impacts on the soil microbial ecology or microbiome has direct implications for food systems (Wall et al., 2015; Andriuzzi et al., 2018). CEC impacts the natural regulation of infectious diseases by exposing humans to animal-borne pathogens, and promoting antimicrobial resistance indirectly as a 
result of antibiotic use in animal agriculture (McCrakin et al., 2016; Helke et al., 2017). CEC also impacts food safety: rises in temperature and changing precipitation patterns can impact the presence of bacteria, viruses, and parasites responsible for food-borne diseases and zoonotic diseases; flooding and droughts can contaminate agricultural soils (Tirado et al., 2010).

Recent findings include evidence that changes in the diversity of animal or human gut microbiome can cause immune dysfunction and increase susceptibility to both infection and, in humans, non-communicable diseases (NCDs) (CBD-WHO, 2015). Shifts in the gut microbiome may be associated with shifting dietary patterns due to changes in dietary quality or nutrition transitions from traditional dietary patterns (Popkin and Gordon-Larsen, 2004; Crittenden and Schnorr, 2017). Additional implications of the intersection of CEC, the gut microbiome and health include increased exposure to antibiotics either directly via medical treatment or indirectly via use in animal production practices (Mie et al., 2017), reduced food and water safety resulting in increased risk of diarrheal disease (Levy et al., 2016), and interactions between microbial diversity, health and nutritional status (Duffy et al., 2015; Shibata et al., 2017).

\section{Nutrition Ecology}

The intersections of CEC, food systems, and nutrition are complex (Raiten and Aimone, 2017). Understanding this nexus requires an ontological approach in which the nature of these relationships can be described. One such approach is nutrition ecology, which considers the effects of CEC on the ecologies of food systems and nutrition, including land/water access and quality, air quality, temperature, weather, food safety, human use patterns, and our efforts for their remediation. In application, this approach can not only identify specific diet/nutrition-related outcomes of CEC, but also minimize the risks of programs designed to address impact on global health having unintended consequences on the environment, land use patterns, and so on.
Nutritional ecological approaches acknowledge that food systems are affected by multiple factors, many of which differ according to local contexts (Box 7.1). For example, as discussed earlier, CEC may increase the yields of some crops, but reduce yields of others. Similarly, CEC may increase agricultural productivity in some locales, but reduce it in others. Therefore, effective programs need to be locally indexed and comprehensive, including assessments of land use/ availability, crop responses, and food and nutrition security. This is the advantage of using nutrition ecology as a framework from which to analyze CEC.

\section{The biological context}

The term 'nutritional status' describes the physiologically active (or potentially active) amount of a given nutrient in an individual's body, and is typically expressed in terms related to statistically derived 'norms'. Individuals are thereby categorized as 'adequate', 'marginal' or 'deficient' with respect to the nutrient(s) analyzed. In practice, this terminology is most useful when referenced to those nutrients that are dietary essentials and are frequently underconsumed (e.g. iron, calcium, magnesium, vitamin A, vitamin D, vitamin $\mathrm{E}$, vitamin $\mathrm{C}$, thiamin, riboflavin, vitamin $\mathrm{B}_{6}$, vitamin $\mathrm{B}_{12}$, total protein, essential fatty acids). Adequate nutritional status is achieved by having an accessible supply of nutrients in biologically available forms, and by being able to perform the various physiological processes required for their utilization (i.e. ingestion, digestion, absorption, metabolism, transport and integration into dependent biological systems to support growth, development and health). Each of these processes can be affected by the health and developmental stage of the individual. These relationships tend to be reciprocal in nature, many involving feedback regulation. Such scenarios make the ecological approach useful in the evaluation of nutritional status, as well as the safety/efficacy of drugs and other xenobiotics which similarly affect and are affected by nutrition (Raiten, 2011). This approach includes considering the presence of infections or NCDs and/or other environmental exposures (air, food, water). 
Box 7.1. Components of the nutrition ecology.

\section{Biological}

- Endogenous factors: genetics, developmental stage, relationships between physiological systems

- Health context: infection, NCDs, inflammation

- Microbiome

- Food safety and impacts on health

Natural Environment

- $\quad$ Climate: impacts on weather (severe weather, floods, drought, etc.)

- Impacts of industrialization: effects on water quality, exposure to toxins

- Water: supply, access, sanitation

- Food systems: indigenous foods, monocultures

Socio-economic Environment

- Community

- Social/cultural factors that influence healthcare delivery/practices

- The 'built environment' - physical facilitators/barriers to food security and health

- Household

- Women's roles in childcare, diet (procurement, production), household decision-making, education

- Role of family in development of healthy behaviors

- Economic development context (health disparity)

- Food insecurity and mitigating factors (e.g. HIV/AIDS)

- Access to healthcare/services

- Consumer 'drivers', e.g. disposable household income; increasing demands for western-type dietary patterns

- The 'Nutrition Transition'

Nutritional status affects many physiological systems needed to respond to health challenges, as well as to a community's ability to work and sustain agricultural and economic development. Some of the ways in which poor nutrition can affect human health and performance are as follows:

- Impaired women's health.

- Poor birth outcomes.

- Poor child growth, neurodevelopment.

- Compromised immunocompetence leading to increased disease risk:

- Diseases (HIV, TB, malaria);

- Infectious diseases (e.g. Zika) and NCDs.

- Compromised ability to deal with xenobiotics (drugs, toxins).

- Compromised work capacity.

The vicious cycle of food insecurity leading to poor diet, malnutrition and adverse nutritional and health outcomes is depicted in Fig. 7. 1.

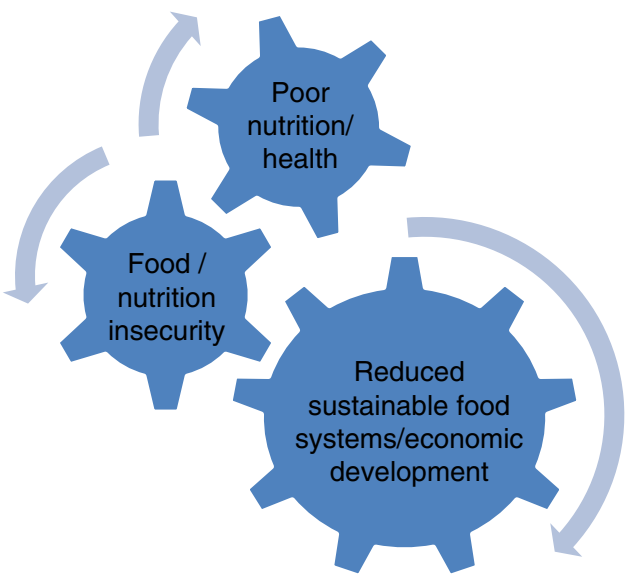

Fig. 7.1. Vicious cycle of food/nutritional insecurity, malnutrition and sustainability.

Superimposed on the daunting challenges of global hunger and malnutrition is a complex global health context. Figure 7.2 depicts the intersection of malnutrition (over/under, 'dual 


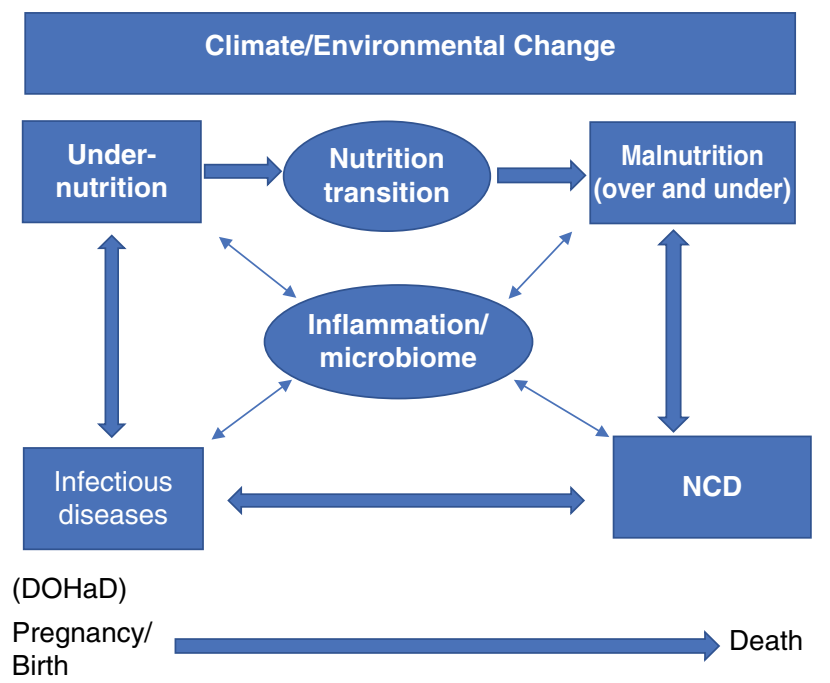

Fig. 7.2. Nutrition, health and CEC (from Raiten et al., 2015).

burden') and diet-associated NCDs (obesity, diabetes, cancer, cardiovascular disease). These problems often occur simultaneously with the persistent burden of such pandemic infections as HIV/AIDS, malaria, tuberculosis (TB), diarrheal diseases along with emerging new infections such as the Zika virus. This global health scenario is depicted in Fig. 7.2.

\section{Implications for nutritional assessment}

CEC affects food systems, nutrition and health. An ecological integrated approach is needed to meet the challenge of how to measure these relationships in a rigorous and reliable manner. Traditional, non-ecological approaches that focus solely on food production and availability are likely to be insufficient in this regard. For example, economic and public health perspectives tend to infer nutritional status by measuring access to foods and patterns of food consumption. Individual nutritional status is typically inferred from the biochemical/physiological biomarkers of a relatively few key nutrients. With the absence of other measures reflecting function of specific biological systems (e.g. hemoglobin, growth or grip strength), these approaches provide little information about how apparent nutritional status was achieved or its effect.

The three classes of measures that represent the continuum of assessment from status to function/effect and public health outcomes are summarized in Box 7.2. Which category is used and how it is interpreted will define the expectations regarding their utility. The ability to assess the impacts of CEC on health via nutrition in individuals and populations will necessitate further development and inclusion of each.

The need for an integrated approach is exemplified by the emerging understanding of the importance of inflammation. Nutritional status can affect, and be affected by, inflammation (Raiten et al., 2015). Of practical concern is the impact of inflammation on the interpretation of biomarkers of nutritional status. For example, many biomarkers such as serum ferritin are used to assess status and make decisions about dietary adequacy. Yet the circulating levels of these biomarkers are directly affected by the acute phase response to inflammation, such that their concentrations may be the result of a physiological response to inflammation rather than a dietary insufficiency (Suchdev et al., 2016). Decisions made using these biomarkers and not accounting for the impact of inflammation in their interpretation can result in giving a nutrient like iron to someone who is, in fact, not deficient. Such an interpretation can under certain circumstances place patients at risk for adverse effects (Raiten and Ashour, 2015). Therefore, inflammatory status must be considered as part of nutritional assessment to avert drawing spurious conclusions about nutritional needs, particularly in cases 
Box 7.2. Tools measuring nutritional status in ecological contexts (Raiten and Combs, 2015).

Biomarkers:

- Sensitive, specific measures of nutrient exposure, status and function; interpreted in individual biological contexts to distinguish between physiology and nutritional need.

- Reflect the actual 'effect' of a particular nutrient status or intervention.

- Currently, those of nutrient exposure are of limited value; they may detect a unique food component, but few have been validated in practical contexts.

Bio-indicators:

- Sentinel measures of functional change due to changes in nutritional status, disease or intervention (e.g., measures of neurological function, growth, immune function, hematology).

- Lack sensitivity and specificity as sole measures of nutritional status, but have value when used with biomarkers of particular nutrients.

Public Health Indicators

- Non-specific and non-sensitive with regard to nutrition and health.

- Reflect 'system' responses and/or shifts in response to population manipulation.

- Because of their systems context, they are similar to 'bio-indicators'; it may be possible to use nutritional biomarkers as bio-indicators of changes in food/economic systems if expectations about responses are constrained to avoid making decisions out of context.

where biomarkers may reflect a physiological response rather than a dietary imbalance.

Because ecological approaches to assessing nutritional status yield more complete views of local contexts, they are likely to be more useful in understanding and addressing the impacts of CEC and, especially, in reducing risks of unintended consequences of well intentioned interventions. They will also facilitate the inclusion of nutritional status in evidence-based clinical decisions, designing population-based interventions and standards of care, and developing effective policies to address the complex global health context affected by CEC.

\section{Avoiding unintended consequences of interventions}

Addressing the food-system impacts of CEC carries the risk of unintended consequences. For example, increasing production of energydense staple grains to ameliorate food insecurity related to a changing climate may be associated with increases in obesity risk, micronutrient malnutrition and NCDs if those crops displace pulses and other nutrient-dense crops. The decision to use food or supplement-based interventions intended to prevent or treat iron-deficiency anemia in women and children vulnerable to the effects of CEC may raise the risk of clinical infections, particularly in areas of endemic malaria (Mwangi et al., 2017). Economic programs designed to improve household disposable incomes among communities negatively impacted by CEC may lead to a demise in traditional dietary patterns with increasing reliance on commercially processed foods (Popkin et al., 2004). Promotion of animal agriculture to address dietary needs for protein and vitamin $\mathrm{B}_{12}$ may increase GHGEs. Efforts to create diets that are associated with a low-carbon footprint (i.e. reduced contribution of GHGE) may not meet dietary quality needs (Payne et al., 2016). Table 7.1 includes some examples of how an ecological approach might be applied to mitigate the likelihood of such unintended consequences.

\section{Integration to Effective Implementation}

CEC is a compelling issue that will require a comprehensive response. Much needs to be done to understand and then accommodate the effects of CEC on food and economic systems to assure their sustainability. A full appreciation of the nature of these relationships requires an 
Table 7.1. Nutritional ecological approaches to addressing CEC.

\begin{tabular}{|c|c|c|}
\hline Challenge & CEC impact & Nutritional ecology approach \\
\hline $\begin{array}{l}\text { Improving food } \\
\text { security and diet } \\
\text { diversity }\end{array}$ & $\begin{array}{l}\text { Changes in crop yields } \\
\text { Crop losses due to severe weather } \\
\text { Adverse impacts on land, air and } \\
\text { water resources } \\
\text { Reduced biodiversity } \\
\text { Changes in food composition }\end{array}$ & $\begin{array}{l}\text { Understand food consumption patterns } \\
\text { Assess health context to determine impacts } \\
\text { (reduced intake, altered dietary patterns, } \\
\text { effects on nutrient needs, responses to } \\
\text { disease and/or treatment) }\end{array}$ \\
\hline $\begin{array}{l}\text { Addressing } \\
\text { micronutrient } \\
\text { malnutrition }\end{array}$ & $\begin{array}{l}\text { Increased food insecurity } \\
\text { Reduced nutritional values of plant } \\
\text { foods } \\
\text { Reduced options for biofortification } \\
\text { Demises of traditional food } \\
\text { practices }\end{array}$ & $\begin{array}{l}\text { Assess food/nutritional security } \\
\text { Assess limiting nutrient status } \\
\text { Evaluate safety and efficacy of available } \\
\text { intervention strategies: assessment of health } \\
\text { context (infectious and NCD); relevant } \\
\text { biomarkers; therapeutics/toxin exposures }\end{array}$ \\
\hline $\begin{array}{l}\text { Addressing the } \\
\text { 'nutrition transition' }\end{array}$ & $\begin{array}{l}\text { Reduced availability of traditional } \\
\text { foods capable of meeting } \\
\text { nutritional needs } \\
\text { Reduced access to arable land to } \\
\text { support sustainable agriculture } \\
\text { Increased pressure towards use of } \\
\text { processed foods } \\
\text { Reduced supplies of traditional } \\
\text { animal/marine sources }\end{array}$ & $\begin{array}{l}\text { Assess local cultural trends/traditional diets } \\
\text { Assess changes in individual/ household } \\
\text { food consumption } \\
\text { Nutritional assessment } \\
\text { Assess attitudes/beliefs regarding } \\
\text { food/dietary patterns including schools } \\
\text { Resource constraints at household/ } \\
\text { community levels }\end{array}$ \\
\hline Ensuring food safety & $\begin{array}{l}\text { Rise in food-borne bacteria, } \\
\text { viruses, and parasites } \\
\text { Contamination of soil and water } \\
\text { through extreme weather events }\end{array}$ & $\begin{array}{l}\text { Assess how different actors ensure food } \\
\text { safety along food value chains } \\
\text { Understand impact of food-borne and } \\
\text { zoonotic diseases on human health }\end{array}$ \\
\hline $\begin{array}{l}\text { Understanding safety } \\
\text { and efficacy of } \\
\text { 'low-carbon } \\
\text { footprint' diets }\end{array}$ & $\begin{array}{l}\text { Efforts to reduce GHGE by } \\
\text { producing diets with low 'carbon } \\
\text { footprints' }\end{array}$ & $\begin{array}{l}\text { Address capability of such diets to meet } \\
\text { nutritional needs } \\
\text { Assess economic implications for } \\
\text { consumers' sustainability } \\
\text { Assess feasibility and sustainability at scale }\end{array}$ \\
\hline $\begin{array}{l}\text { Meeting dietary } \\
\text { guidelines } \\
\text { including disease } \\
\text { prevention (NCD) }\end{array}$ & $\begin{array}{l}\text { Reduced capacities of food } \\
\text { systems to provide healthful } \\
\text { balances of fruits, vegetables } \\
\text { and animal source foods }\end{array}$ & $\begin{array}{l}\text { Assess agriculture capacity and sustainability } \\
\text { of resource use (land, water, economics) } \\
\text { Assess economic impact of changes to } \\
\text { agricultural practices } \\
\text { Assess food quality and acceptability by } \\
\text { local consumers }\end{array}$ \\
\hline $\begin{array}{l}\text { Addressing current } \\
\text { and emerging } \\
\text { infections }\end{array}$ & $\begin{array}{l}\text { Reduced water/food safety } \\
\text { Losses of crop biodiversity } \\
\text { Increases in vector-borne diseases }\end{array}$ & $\begin{array}{l}\text { Assess health context with emphases on } \\
\text { at-risk groups (women/infants, elderly) } \\
\text { Assess water/food safety practices } \\
\text { Assess impacts on nutritional status }\end{array}$ \\
\hline
\end{tabular}

ecological approach to integrate the biology and health contexts in determining best responses.

Such efforts will benefit from the nutritional ecology perspective, which will facilitate integrating relevant needs and available knowledge into effective and sustainable interventions/programs. This perspective will include the following:

- Basic biomedical/clinical/plant/animal science research - to understand the nature and mechanisms of problems related to $\mathrm{CEC}$, disease, toxicology, and all aspects of human growth and development.

- Knowledge translation - to devise best practices in clinical assessment and surveillance in identifying problems as they occur in individuals and populations.

- Interventions - to address problems in sustainable (environmentally, economically, and culturally) and biologically relevant/ efficacious ways. These include nutritionspecific and sensitive interventions including 
sustainable food production practices for crops and fisheries.

- Implementation - to identify the stakeholders needed roll-out/scale-up effective programs at local/community, national and global levels.

- Monitoring and evaluation - to effect timely and appropriate programs/policies with effective and continuous feedback to enable sustained responsiveness to continued change.

That the elements of the nutrition ecology interact in non-linear ways provides both needs and opportunities for their continuous analysis. Therefore, effective data inputs/outputs are needed to monitor and evaluate existing programs/policies to be responsive to environmental and technological changes while minimizing risks of unintended consequences.

\section{Conclusion}

The global imperative is complex: to support stable, healthy dietary patterns that are environmentally friendly (particularly regarding
GHGE) and are acceptable across a range of culturally diverse settings. Ultimately, the purpose of agriculture is to support human health and well-being. Translating available knowledge about the relationships of diet and health depends on developing evidence-informed guidelines and specific health targets. Following those guidelines and meeting those targets will depend on having sustainable food supplies. The challenge is to accomplish that goal in the face of CEC (Aleksandrowicz et al., 2016; Horgan et al., 2016; Péneau et al., 2017; Perignon et al., 2017; Ridoutt et al., 2017). CEC is exerting profound effects on current and potentially future efforts to feed and care for a hungry planet. Its impacts on land/marine food systems are clear and significant. The effects of CEC are not limited to food systems; they also threaten health. Nutrition serves as the biological variable of health that links these effects. We have laid out a conceptual framework for why and how the elements of the nutrition ecology must be integrated into efforts moving forward to sustain global food production and improve human health in the face of CEC. This approach will facilitate the development of effective responses to one of the most compelling challenges of our time.

\section{References}

Aleksandrowicz, L., Green, R., Joy, E.J., Smith, P. and Haines, A. (2016) The impacts of dietary change on greenhouse gas emissions, land use, water use, and health: a systematic review. PLOS ONE 11(11): e0165797. doi: 10.1371/journal.pone.0165797.

Ali, S., Liu, Y., Ishaq, M., Shah, T., Abdullah, A., Ilyas, A. and Din, I.U. (2017) Climate change and its impact on the yield of major food crops: evidence from Pakistan. Foods 6(6), 39. doi: 10.3390/foods6060039.

Andriuzzi, W.S., Adams, B.J., Barrett, J.E., Virginia, R.A. and Wall, D.H. (2018) Observed trends of soil fauna in the Antarctic Dry Valleys: early signs of shifts predicted under climate change. Ecology 99(2), 312-321. doi: 10.1002/ecy.2090.

Bailey, R.L., West, K.P. Jr and Black, R.E. (2015) The epidemiology of global micronutrient deficiencies. Annals of Nutrition Metabolism 66 (Suppl. 2), 22-33. doi: 10.1159/000371618.

Brown, M.J., Dicks, L.V., Paxton, R.J., Baldock, K.C., Barron, A.B. et al. (2016) A horizon scan of future threats and opportunities for pollinators and pollination. PeerJ 4, e2249. doi: 10.7717/peerj.2249.

CBD-WHO (2015) Connecting Global Priorities: Biodiversity and Human Health. A State of Knowledge Review. Convention on Biological Diversity (Montreal) and World Health Organization (Geneva).

Crittenden, A.N. and Schnorr, S.L. (2017) Current views on hunter-gatherer nutrition and the evolution of the human diet. American Journal of Physical Anthropology 162 (Suppl. 63), 84-109. doi: 10.1002/ajpa.23148.

Donatelli, M., Kumar Srivastava, A., Duveiller, G., Niemeyer, S. and Fumagalli, D. (2015) Climate change impact and potential adaptation strategies under alternate realizations of climate scenarios for three major crops in Europe. Environmental Research Letters 10(7), 075005.

Donatelli, M., Magarey, R.D., Bregaglio, S., Willocquet, L., Whish, J.P.M. and Savary, S. (2017) Modelling the impacts of pests and diseases on agricultural systems. Agricultural Systems 155, 213-224. doi: 10.1016/j.agsy.2017.01.019. 
Duffy, L.C., Raiten, D.J., Hubbard, V.S. and Starke-Reed, P. (2015) Progress and challenges in developing metabolic footprints from diet in human gut microbial co-metabolism. Journal of Nutrition 145, 1123S-1130S.

Ellis, A.M., Myers, S.S. and Ricketts, T.H. (2015) Do pollinators contribute to nutritional health? PLOS ONE 10(1), e114805. doi: 10.1371/journal.pone.0114805.

FAO (2016) The State of World Fisheries and Aquaculture 2016. Contributing to food security and nutrition for all. Food and Agriculture Organization of the United Nations, Rome. Available at: https://reliefweb. int/report/world/state-world-fisheries-and-aquaculture-2016 (accessed 19 December 2018).

FAO, IFAD, UNICEF, WFP and WHO (2017) The State of Food Security and Nutrition in the World 2017. Building resilience for peace and food security. Food and Agriculture Organization of the United Nations, Rome.

Farchi, S., De Sario, M., Lapucci, E., Davoli, M. and Michelozzi, P. (2017) Meat consumption reduction in Italian regions: health co-benefits and decreases in GHG emissions. PLOS ONE 12(8), e0182960. doi: 10.1371/journal.pone.0182960.

Garzke, J., Hansen, T., Ismar, S.M.H. and Sommer, U. (2016) Combined effects of ocean warming and acidification on copepod abundance, body size and fatty acid content. PLOS ONE 11(5), e0155952. doi:10.1371/journal.pone.0155952. Available at: http://journals.plos.org/plosone/article?id=10.1371/ journal.pone.0155952 (accessed 19 December 2018).

Gerber, P.J., Steinfeld, H., Henderson, B., Mottet, A., Opio, C. et al. (2013) Tackling Climate Change Through Livestock - a Global Assessment of Emissions and Mitigation Opportunities. Food and Agriculture Organization (FAO) of the United Nations, Rome.

Golden, C.D., Allison, E.H., Cheung, W.W.L., Dey, M.M., Halpern, B.S. et al. (2016) Fall in fish catch threatens human health. Nature 534, 317-320.

Goldstein, B., Moses, R., Sammons, N. and Birkved, M. (2017) Potential to curb the environmental burdens of American beef consumption using a novel plant-based beef substitute. PLOS ONE 12(12), e0189029. doi: 10.1371/journal.pone.0189029.

Gomez-Gutierrez, C.M., Guerra-Rivas, G., Soria-Mercado, I.E. and Ayala-Sánchez, N.E. (2011) Marine edible algae as disease preventers. Advances in Food and Nutrition Research 64, 29-39. doi: 10.1016/ B978-0-12-387669-0.00003-X.

Hasegawa, S., Macdonald, C.A. and Power, S.A. (2016) Elevated carbon dioxide increases soil nitrogen and phosphorus availability in a phosphorus-limited Eucalyptus woodland. Global Change Biology 22(4), 1628-1643. doi: 10.1111/gcb.13147.

Helke, K.L., McCrackin, M.A., Galloway, A.M., Poole, A.Z., Salgado, C.D. and Marriott, B.P. (2017) Effects of antimicrobial use in agricultural animals on drug-resistant foodborne salmonellosis in humans: a systematic literature review. Critical Reviews in Food Science and Nutrition 57(3), 472-488.

Henchion, M., Hayes, M., Mullen, A.M., Fenelon, M., Tiwari, B. (2017) Future protein supply and demand: strategies and factors influencing a sustainable equilibrium. Foods 6(7), E53. doi: 10.3390/ foods6070053.

Horgan, G.W., Perrin, A., Whybrow, S. and Macdiarmid, J.I. (2016) Achieving dietary recommendations and reducing greenhouse gas emissions: modelling diets to minimise the change from current intakes. International Journal of Behavioral Nutrition and Physical Activity 13, 46. doi: 10.1186/s12966-0160370-1.

Kumar, M. (2016) Impact of climate change on crop yield and role of model for achieving food security. Environmental Monitoring and Assessment 188(8), 465. doi: 10.1007/s10661-016-5472-3.

Latunde-Dada, G.O., Yang, W. and Vera Aviles, M. (2016) In vitro iron availability from insects and sirloin beef. Journal of Agricultural Food Chemistry 64(44), 8420-8424.

Lee, S.G., Kim, S.K., Lee, H.J., Lee, H.S. and Lee, J.H. (2017) Impact of moderate and extreme climate change scenarios on growth, morphological features, photosynthesis, and fruit production of hot pepper. Ecology and Evolution 8(1), 197-206. doi: 10.1002/ece3.3647.

Levy, K., Woster, A.P., Goldstein, R.S. and Carlton, E.J. (2016) Untangling the impacts of climate change on waterborne diseases: a systematic review of relationships between diarrheal diseases and temperature, rainfall, flooding, and drought. Environmental Science and Technology 50(10), 4905-4922. doi: 10.1021/acs.est.5b06186.

McCrackin, M.A., Helke, K.L., Galloway, A.M., Poole, A.Z., Salgado, C.D. and Marriott, B.P. (2016) Effect of antimicrobial use in agricultural animals on drug-resistant foodborne campylobacteriosis in humans: a systematic literature review. Critical Reviews in Food Science and Nutrition 56(13), 2115-2132. doi: 10.1080/10408398.2015.1119798. 
Medek, D.E., Schwartz, J. and Myers, S.S. (2017) Estimated effects of future atmospheric $\mathrm{CO}_{2}$ concentrations on protein intake and the risk of protein deficiency by country and region. Environmental Health Perspectives 125(8), 087002-1-8. doi: 10.1289/EHP41.

Mie, A., Andersen, H.R., Gunnarsson, S., Kahl, J., Kesse-Guyot, E. et al. (2017) Human health implications of organic food and organic agriculture: a comprehensive review. Environmental Health 16(1), 111. doi: 10.1186/s12940-017-0315-4.

Mwangi, M.N., Prentice, A.M. and Verhoef, H. (2017) Safety and benefits of antenatal oral iron supplementation in low-income countries: a review. British Journal of Haematology 177(6), 884-895. doi: 10.1111/bjh.14584.

Myers, S.S., Zanobetti, A., Kloog, I., Huybers, P., Leakey, A.D.B. et al. (2014) Rising $\mathrm{CO}_{2}$ threatens human health. Nature 510, 139-142.

Myers, S.S., Wessells, K.R., Kloog, I., Zanobetti, A. and Schwartz, J. (2015) Effect of increased concentrations of atmospheric carbon dioxide on the global threat of zinc deficiency: a modelling study. The Lancet Global Health 3, e639-e645.

Newbery, F., Qi, A. and Fitt, B.D. (2016) Modelling impacts of climate change on arable crop diseases: progress, challenges and applications. Current Opinion in Plant Biology 32,101-109. doi: 10.1016/j. pbi.2016.07.002.

Niinemets, Ü., Berry, J.A., von Caemmerer, S., Ort, D.R., Parry, M.A. and Poorter, H. (2017) Photosynthesis: ancient, essential, complex, diverse ... and in need of improvement in a changing world. New Phytologist 213(1), 43-47.

NOAA NCEI (2017) State of the Climate: Global Climate Report for Annual 2017. National Ocean and Atmospheric Administration/National Centers for Environmental Information, Asheville, North Carolina. Published online January 2018. Available at: https://www.ncdc.noaa.gov/sotc/global/201713 (accessed 26 September 2018).

O’Brien, D.M., Thummel, K.E., Bulkow, L.R., Wang, Z., Corbin, B. et al. (2017) Declines in traditional marine food intake and vitamin D levels from the 1960s to present in young Alaska Native women. Public Health Nutrition 20(10), 1738-1745. doi: 10.1017/S1368980016001853.

Pauls, S.U., Nowak, C., Bálint, M. and Pfenninger, M. (2013) The impact of global climate change on genetic diversity within populations and species. Molecular Ecology 22(4), 925-946. doi: 10.1111/mec.12152.

Payne, C.L., Scarborough, P. and Cobiac, L. (2016) Do low-carbon-emission diets lead to higher nutritional quality and positive health outcomes? A systematic review of the literature. Public Health Nutrition 9(14), 2654-2661.

Péneau, S., Fassier, P., Allès, B., Kesse-Guyot, E., Hercberg, S. and Méjean, C. (2017) Dilemma between health and environmental motives when purchasing animal food products: sociodemographic and nutritional characteristics of consumers. BMC Public Health 17(1), 876. doi: 10.1186/s12889-017-4875-6.

Perignon, M., Vieux, F., Soler, L.G., Masset, G. and Darmon, N. (2017) Improving diet sustainability through evolution of food choices: review of epidemiological studies on the environmental impact of diets. Nutrition Reviews 75(1), 2-17.

Pinkney, A.E., Driscoll, C.T., Evers, D.C., Hooper, M.J., Horan, J. et al. (2015) Interactive effects of climate change with nutrients, mercury, and freshwater acidification on key taxa in the North Atlantic Landscape Conservation Cooperative region. Integrated Environmental Assessment and Management 11(3), 355-369. doi: 10.1002/ieam.1612.

Popkin, B.M. and Gordon-Larsen, P. (2004) The nutrition transition: worldwide obesity dynamics and their determinants. International Journal of Obesity and Related Metabolic Disorders 28(Suppl. 3), S2-S9.

Raiten, D.J. (2011) Nutrition and pharmacology: general principles and implications for HIV. American Journal of Clinical Nutrition 94(6), 1697S-1702S. doi: 10.3945/ajcn.111.019109.

Raiten, D.J. and Aimone, A.M. (2017) The intersection of climate/environment, food, nutrition and health: crisis and opportunity. Current Opinion in Biotechnology 44, 52-62. doi: 10.1016/j.copbio.2016.10.006.

Raiten, D.J. and Ashour, F.A. (2015) Iron: Current landscape and efforts to address a complex issue in a complex world. Journal of Pediatrics 167(4 Suppl.), S3-7. doi: 10.1016/j.jpeds.2015.07.013.

Raiten, D.J. and Combs, G.F. (2015) Directions in nutritional assessment - biomarkers and bio-indicators: providing clarity in the face of complexity. Sight and Life 29(1), 39-44.

Raiten, D.J., Sakr Ashour, F.A., Ross, A.C., Meydani, S.N., Dawson, H.D. et al. (2015) Inflammation and Nutritional Science for Programs/Policies and Interpretation of Research Evidence (INSPIRE). Journal of Nutrition 145(5), 1039S-1108S. doi: 10.3945/jn.114.194571.

Ridoutt, B.G., Hendrie, G.A. and Noakes, M. (2017) Dietary strategies to reduce environmental impact: a critical review of the evidence base. Advances in Nutrition 8(6), 933-946. 
Rossoll, D., Bermúdez, R., Hauss, H., Schulz, K.G., Riebesell, U., Sommer, U. and Winder, M. (2012) Ocean acidification-induced food quality deterioration constrains trophic transfer. PLOS ONE 7(4), e34737. doi: 10.1371/journal.pone.0034737.

Shibata, N., Kunisawa, J. and Kiyono, H. (2017) Dietary and microbial metabolites in the regulation of host immunity. Frontiers in Microbiology 7(8), 2171. doi: 10.3389/fmicb.2017.02171.

Suchdev, P.S., Namaste, S.M., Aaron, G.J., Raiten, D.J., Brown, K.H. and Flores-Ayala, R. (2016) Overview of the Biomarkers Reflecting Inflammation and Nutritional Determinants of Anemia (BRINDA) Project. Advances in Nutrition 7(2), 349-356. doi: 10.3945/an.115.010215.

Tai, A.P.K., Martin, M.V. and Heald, C.L. (2014) Threat to future global food security from climate change and ozone air pollution. Nature Climate Change 4(9), 817-821. doi: proxy.lib.umich.edu/10.1038/nclimate2317.

Thornton, P. and Cramer, L. (eds) (2012) Impacts of Climate Change on the Agricultural and Aquatic Systems and Natural Resources Within the CGIAR's Mandate. CCAFS Working Paper No. 23. CGIAR Research Program on Climate Change, Agriculture and Food Security (CCAFS), Copenhagen, Denmark. Available at: http://www.ccafs.cgiar.org (accessed 19 December 2018).

Tirado, M.C., Clarke, R., Jaykus, L.A., McQuatters-Gollop, A. and Frank, J. (2010) Climate change and food safety: a review. Food Research International 34(7), 1745-1765.

UNHCR (2018) Climate Change and Disasters. United Nations High Commissioner for Refugees, Geneva. Available at: http://www.unhcr.org/en-us/climate-change-and-disasters.html (accessed 26 September 2018).

UN DESA (2017) World Population Prospects: The 2017 Revision. United Nations Department of Economic and Social Affairs, Population Division. Available at: https://population.un.org/wpp/ (accessed 25 September 2018).

Van Huis, A. (2016) Edible insects are the future? Proceedings of the Nutrition Society 75(3), $294-305$. doi: 10.1017/S0029665116000069.

Walker, B.J., Orr, D.J., Carmo-Silva, E., Parry, M.A.J., Bernacchi , C.J. and Ort, D.R. (2017) Uncertainty in measurements of the photorespiratory $\mathrm{CO}_{2}$ compensation point and its impact on models of leaf photosynthesis. Photosynthesis Research 132(3), 245-255.

Wall, D.H., Nielsen, U.N. and Six, J. (2015) Soil biodiversity and human health. Nature 528, 69-76.

White, R.R. and Hall, M.B. (2017) Nutritional and greenhouse gas impacts of removing animals from US agriculture. Proceedings of the National Academy of Sciences, USA 114(48), E10301-E10308. doi: 10.1073/pnas.1707322114.

Whitmee, S., Haines, A., Beyrer, C., Boltz, F., Capon, A.G. et al (2015) Safeguarding human health in the Anthropocene epoch: report of The Rockefeller Foundation-The Lancet Commission on planetary health. The Lancet 386(10007), 1973-2028. doi: 10.1016/S0140-6736(15)60901-1.

WWF (2015) Living Blue Planet: crisis in global oceans as populations of marine species halve in size since 1970. World Wildlife Federation, Gland, Switzerland. Available at: http://assets.wwf.org.uk/ downloads/living_blue_planet_report_2015.pdf (accessed 19 December 2018).

Zabel, F., Putzenlechner, B. and Mauser, W. (2014) Global agricultural land resources - a high resolution suitability evaluation and its perspectives until 2100 under climate change conditions. PLOS ONE 9(9), e107522. doi: 10.1371/journal.pone.0107522.

Zhang, X. and Cai, X. (2011) Climate change impacts on global agricultural land availability. Environmental Research Letters 6, 014014.

Zhao, J., Pu, F., Li, Y., Xu, J., Li, N., Zhang, Y., Guo, J. and Pan, Z. (2017) Assessing the combined effects of climatic factors on spring wheat phenophase and grain yield in Inner Mongolia, China. PLOS ONE 12(11), e0185690. doi: 10.1371/journal.pone.0185690.

Ziska, L.H. and McConnell, L.L. (2016) Climate change, carbon dioxide, and pest biology: monitor, mitigate, manage. Journal of Agricultural and Food Chemistry 64(1), 6-12. doi: 10.1021/jf506101h.

Ziska, L.H., Epstein, P.R. and Schlesinger, W.H. (2009) Rising CO(2), climate change, and public health: exploring the links to plant biology. Environmental Health Perspectives 117, 155-158.

Ziska, L., Crimmins, A., Auclair, A., DeGrasse, S., Garofalo, J.F. et al. (2016) Food safety, nutrition, and distribution. In: The Impacts of Climate Change on Human Health in the United States: A Scientific Assessment. US Global Change Research Program, Washington, DC, pp. 189-216. doi: 10.7930/ J0ZP4417. 